\title{
Pemetaan Kesesuaian Perairan untuk Budidaya Laut di Perairan Pesisir Kabupaten Situbondo dan Banyuwangi Jawa Timur
}

\author{
Zainul Hidayah $^{1^{*}}$, Apri Arisandi2), Maulinna Kusumo Wardhani ${ }^{1,3)}$ \\ ${ }^{1}$ Program Studi Ilmu Kelautan, Fakultas Pertanian, Universitas Trunojoyo Madura \\ ${ }^{2}$ Program Studi Pasca Sarjana Pengelolaan Sumber Daya Alam, Fakultas Pertanian \\ Universitas Trunojoyo Madura \\ ${ }^{3}$ Mahasiswa Program Doktor Fakultas Teknologi Kelautan, Institut Teknologi Sepuluh Nopember Surabaya \\ *zainulhidayah@trunojoyo.ac.id \\ DOI: https://doi.org/10.21107/rekayasa.v13i3.9858
}

\begin{abstract}
Pemilihan lokasi merupakan langkah awal untuk penentuan kegiatan perikanan budidaya laut yang berkelanjutan. Dokumen Rencana Zonasi Wilayah Pesisir dan Pulau-Pulau Kecil (RZWP3K) Provinsi Jawa Timur menyebutkan bahwa kawasan pesisir dan laut yang berada di perairan Selat Madura dan Selat Bali, terutama pesisir Kabupaten Situbondo dan Banyuwangi dialokasikan sebagai wilayah pengembangan budidaya laut. Penelitian ini bertujuan untuk menganalisa karakteristik kondisi perairan Kabupaten Situbondo dan Banyuwangi, khususnya mengenai kelayakan sebagai lokasi budidaya laut. Penelitian ini dilaksanakan pada bulan Juni sampai dengan Juli tahun 2020. Pengambilan data sample air laut dilakukan di titik pengamatan yang tersebar di 15 kecamatan pesisir di Kabupaten Situbondo (Selat Madura) dan Banyuwangi (Selat Bali dan Samudera Hindia). Metode yang digunakan adalah dengan menganalisis parameter kualitas perairan dan menghitung nilai indeks kesesuaian. Selain itu dilakukan pula pendugaan besarnya beban limbah dan analisis komponen utama. Hasil penelitian dapat disimpulkan bahwa lokasi yang sesuai untuk pengembangan budidaya laut di Kabupaten Situbondo terletak di Kecamatan Suboh, Kendit, Arjasa dan Jangkar dengan nilai indeks kesesuaian berkisar antara 63,5-67,5. Sementara untuk Kabupaten Banyuwangi, kawasan yang sesuai untuk pengembangan budidaya laut terletak di Kecamatan Wongsorejo dan Muncar dengan nilai indeks antara 64 - 68.5. Estimasi beban limbah menunjukkan bahwa potensi limbah yang terjadi akibat budidaya laut dengan KJA adalah sekitar 0,24 ton N/10 unit karamba. Hasil perhitungan analisis komponen utama menunjukkan stasiun pengamatan memiliki karakteristik nilai parameter kualitas air yang beragam.
\end{abstract}

Keywords: budidaya laut, kesesuaian, analisis komponen utama, karamba jaring apung

\section{PENDAHULUAN}

Budidaya laut merupakan suatu usaha memanfaatkan sumberdaya yang ada di kawasan pesisir dalam hal memelihara berbagai jenis ikan, kerang-kerangan, rumput laut dan biota laut lainnya yang bernilai ekonomis penting. Pengertian lain mengenai budidaya laut adalah suatu kegiatan pada area tertentu di perairan pantai yang dicirikan dengan banyaknya terdapat kumpulan keramba jaring apung, rakitrakit kerang-kerangan atau rumput laut atau membudidayakan organisme laut dalam wadah atau area terbatas dan terkurung (Mustafa et al., 2017). Pengembangan akuakultur di Indonesia diharapkan mampu menjawab empat isu

\section{Article History:}

Received: August, $2^{\text {nd }}$ 2020; Accepted: Dec, $11^{\text {th }} 2020$ Rekayasa ISSN: $2502-5325$ has been Accredited by Ristekdikti (Arjuna) Decree: No. 23/E/KPT/2019 August 8th, 2019 effective until 2023 penting antara lain: 1) keamanan pangan; 2) perikanan yang bertanggung jawab; 3) perdagangan global; 4) memiliki daya saing komperatif yang esensinya berupa peluang pasar bagi produk akuakultur (FAO Fisheries dan Aquaculture Department, 2006). Pengembangan budidaya laut di Indonesia untuk waktu yang akan datang sangat penting artinya bagi pembangunan sub sektor perikanan, serta merupakan salah satu prioritas yang diharapkan menjadi pendorong pertumbuhan ekonomi.

Sumberdaya ikan di laut meskipun merupakan sumberdaya yang dapat pulih kembali, tetapi tetap ada batasan, apabila batas

\section{Cite this as:}

Hidayah, Z; Arisandi, A; Wardhani, M.K (2020). Pemetaan Kesesuaian Perairan untuk Budidaya Laut di Perairan Pesisir Kabupaten Situbondo dan Banyuwangi Jawa Timur. Rekayasa, 13 (3), 299-306.

https://doi.org/10.21107/rekayasa.v13i3.9858

(c) 2020 Zainul Hidayah, Apri Arisandi, Maulinna Kusumo 
tersebut dilampaui akan sangat membahayakan kelestarian sumberdaya ikan dan lingkungan pesisir (Dahuri et.al, 2004; Marpaung et al., 2019). Pemanfaatan sumberdaya ikan di laut di Selat Madura dan Selat Bali sudah intensif dan menunjukkan gejala-gejala padat tangkap, sehingga pengembangan selanjutnya di wilayah perairan tersebut diarahkan ke kegiatan budidaya laut (Effendi, 2003; Idris et al., 2007; Arisandi et al., 2018). Potensi pengembangan budidaya laut yang dimiliki Indonesia sangat besar dengan garis pantai yang panjang, gugusan pulau-pulau, selat dan teluk yang sangat sesuai untuk lahan pengembangan budidaya laut. Oleh karena itu, kegiatan budidaya laut dapat diandalkan sebagai salah satu penyumbang devisa negara, karena komoditas budidaya laut ini mempunyai nilai ekonomis penting seperti ikan kerapu, kakap, tiram mutiara dan lain sebagainya (Parwinia et al., 2007; Syafikri et al., 2019).

Peluang pengembangan usaha budidaya laut di Indonesia masih sangat besar, mengingat pemanfaatan perairan yang dimilikinya sampai saat ini masih relatif rendah. Pemanfaatan potensi sumberdaya ikan di laut baru mencapai $65 \%$, atau baru 4,8 juta ton per tahun dari potensi sumberdaya ikan yang mencapai 6,4 juta ton per tahun (Ditjen. Perikanan Tangkap, 2018). Sementara itu, kondisi global juga menyediakan peluang besar bagi pengembangan perikanan yang ditunjukkan antara lain oleh terus meningkatnya permintaan terhadap ikan dan produk perikanan, berubahnya pola makan dari daging merah (red meat) ke daging putih (white meat), gaya hidup yang lebih berorentasi pada makanan yang nonkolesterol dan lain sebagainya (Arifin et al., 2014; Bramana et al., 2014).

Pemilihan lokasi yang tepat merupakan faktor yang penting dalam menentukan kelayakan usaha budidaya. Beberapa pertimbangan yang yang perlu diperhatikan dalam penentuan lokasi adalah daya dukung ekologi meliputi kondisi teknis yang terdiri dari parameter fisik, kimia dan biologi dan non teknis yang berupa pangsa pasar, keamanan dan dan sumberdaya manusia. Salah satu kesalahan dalam pengembangan budidaya adalah lingkungan perairan yang tidak cocok atau kurang mendukung. Hal ini dapat terjadi karena penentuan lokasi pengembangan budidaya lebih berdasarkan feeling atau trial and error. Oleh karena informasi tentang kelayakan lokasi (site suitability) dan daya dukung sangatlah diperlukan untuk pemanfaatan pesisir, terutama untuk aktivitas budidaya laut. Kesalahan dalam menentukan lokasi dapat menyebabkan kegiatan pemanfaatan ruang pada zona tersebut menjadi tidak tepat.

Pemilihan lokasi merupakan langkah awal untuk penentuan kegiatan perikanan budidaya yang berkelanjutan (Harianto \& Efendi, 2017). Umumnya kesalahan dalam pengembangan kegiatan budidaya laut disebabkan oleh kurangnya pengetahuan tentang lingkungan perairan, dalam hal ini kondisi kualitas perairan memegang peranan penting didalam pemilihan lokasi budidaya (Yunus et al., 2019). Identifikasi kelayakan dan daya dukung suatu lokasi perairan yang sesuai dengan peruntukannya sangat penting. Hal ini selain menghindarkan dari konflik kepentingan, juga menjamin pemilihan lokasi budidaya laut yang tepat.

Dokumen Rencana Zonasi Wilayah Pesisir dan Pulau-Pulau Kecil (RZWP3K) Provinsi Jawa Timur menyebutkan bahwa kawasan pesisir dan laut yang berada di perairan Selat Madura dan Selat Bali, terutama pesisir Kabupaten Situbondo dan Banyuwangi dialokasikan sebagai wilayah pengembangan budidaya laut. Penelitian ini bertujuan untuk menganalisa karakteristik kondisi perairan Kabupaten Situbondo dan Banyuwangi, khususnya mengenai kelayakan sebagai lokasi budidaya laut. Selanjutnya menggunakan data sebaran spasial stasiun pengamatan, kualitas air dan potensi limbah penelitian ini juga bertujuan untuk menghitung daya dukung lingkungan untuk kegiatan budidaya laut di lokasi studi.

\section{METODE PENELITIAN \\ Pengumpulan data}

Penelitian ini dilaksanakan pada bulan Juni sampai dengan Juli tahun 2020. Pengambilan data sample air laut dilakukan di 42 titik pengamatan yang tersebar di 15 kecamatan pesisir di Kabupaten Situbondo (Selat Madura) dan Banyuwangi (Selat Bali dan Samudera Hindia). Parameter kualitas air laut melalui analisa laboratorium yaitu Oksigen terlarut (DO), kadar Phospat dan Nitrat. 


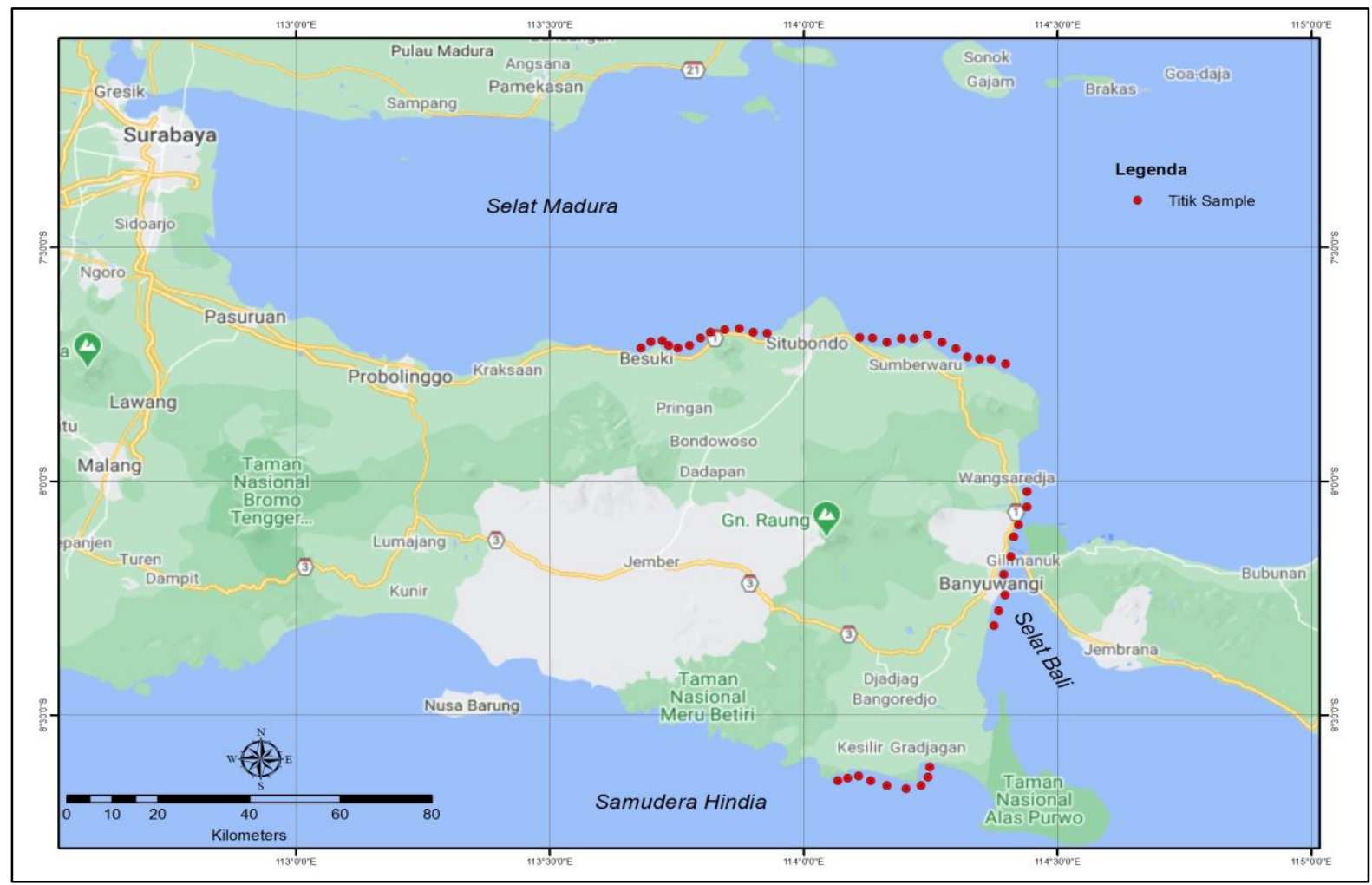

Gambar 1. Lokasi Penaambilan Data

Sedangkan pengukuran langsung di lapangan dilakukan untuk mengetahui nilai parameter suhu, kedalaman perairan, salinitas, $\mathrm{pH}$, kecerahan dan pengaruh gelombang. Untuk memudahkan analisa data spasial, titik-titik pengambilan data didistribusikan sesuai dengan wilayah kecamatan. Sebaran titik pengambilan data dapat dilihat pada Gambar 1.

\section{Penilaian Kesesuaian Lokasi Budidaya Laut}

Penentuan kelayakan perairan untuk pengembangan budidaya dengan sistem keramba jaring apung dilakukan dengan metode pembobotan. Data kondisi fisika dan kimia perairan dijadikan acuan dalam menentukan kriteria kelayakan lahan. Menurut Pramono et al., (2005); Suryanto et al., (2005) dan Cornelia et al., (2005) yang dimodifikasi oleh peneliti didalam melakukan metode scoring, ada empat tahapan yang perlu dilakukan yaitu:

1. Penetapan persyaratan (parameter dan kriteria), pembobotan dan scoring. Parameter yang menentukan diberikan bobot terbesar sedangkan kriteria (batas-batas) yang sesuai diberikan skor tertinggi.

2. Penghitungan nilai peruntukkan lahan budidaya dengan sistem keramba jaring apung. Nilai suatu lahan budidaya ditentukan berdasarkan total hasil perkalian bobot dan skor yang selanjutnya

3. Pendekatan evaluasi kesesuaian perairan yang digunakan adalah metoda pendekatan matematis melalui perkalian dan penjumlahan parameter, sedangkan penilaian kelas kesesuaian dilakukan pada tingkat kelas.

4. Penentuan kesesuaian berdasarkan perkalian skor dan bobot yang diperoleh dari setiap parameter. Kesesuaian kawasan dilihat melalui tingkat persentase kesesuaian dari penjumlahan nilai seluruh parameter. Rumus yang digunakan untuk kesesuaian kawasan budidaya laut adalah (Hutabarat et al. 2009):

$$
I K B=\sum_{i=1}^{n}\left[\frac{N i}{N m a k z}\right] X 100 \%
$$

\section{Keterangan:}

IKB : Indeks Kesesuaian Budidaya

$\mathrm{Ni} \quad$ : Nilai Parameter ke-i (bobot $\mathrm{x}$ skor)

$\mathrm{N}$ maks : Nilai maksimum kategori

Hasil perkalian antara bobot dan skor yang diterima oleh masing-masing coverage tersebut disesuaikan berdasarkan tingkat kepentingannya terhadap penentuan kesesuaian budidaya dengan sistem keramba jaring apung. 
Tabel 1. Kriteria Kesesuaian Budidaya Rumput Laut

\begin{tabular}{|l|c|c|c|c|c|}
\multirow{2}{*}{\multicolumn{1}{c}{ Kriteria }} & \multirow{2}{*}{ Satuan } & \multirow{2}{*}{ Bobot } & \multicolumn{3}{c|}{ Skor } \\
\cline { 4 - 6 } & & & $\mathbf{2}(\mathbf{S 1})$ & $\mathbf{1}$ (S2) & $\mathbf{0}(\mathbf{N})$ \\
\hline Pengaruh Gelombang & & 4 & Kecil & Sedang & Besar \\
\hline Kecepatan Arus & $\mathrm{cm} /$ detik & 4 & $25-30$ & $20-<25$ & $<20$ atau $>30$ \\
\hline Fosfat & $\mathrm{mg} / \mathrm{l}$ & 3 & $0,2-0,5$ & $0,1-0,2$ atau $0,5-1$ & $<0,1$ atau $>1$ \\
\hline Nitrat & $\mathrm{mg} / \mathrm{l}$ & 3 & $0,9-3,2$ & $0,7-0,8$ atau $3,3-3,4$ & $<0,7$ atau $>3,4$ \\
\hline Kedalaman & $\mathrm{m}$ & 3 & $1-10$ & $11-15$ & $<1$ dan $>15$ \\
\hline Kecerahan & $\mathrm{m}$ & 3 & $>3$ & $1-3$ & $<1$ \\
\hline Salinitas & $\% \circ$ & 2 & $30-33$ & 29 atau $>33-35$ & $<29$ atau $>35$ \\
\hline Suhu & ${ }^{\circ} \mathrm{C}$ & 2 & $24-30$ & $20-24$ & $<20$ dan $>30$ \\
\hline Material dasar & & 1 & Karang & Pasir & Pasir berlumpur \\
\hline Oksigen terlarut & $\mathrm{mg} / \mathrm{l}$ & 1 & $>6$ & $4-6$ & $<4$ \\
\hline $\mathrm{pH}$ & & 1 & $6,5-8,5$ & $4-6,4$ dan $8,5-9,0$ & $<4$ dan $>9,5$ \\
\hline
\end{tabular}

Tabel 2. Kriteria Kesesuaian Budidaya Kerapu dengan KJA

\begin{tabular}{|c|c|c|c|c|c|}
\hline \multirow{2}{*}{ Kriteria } & \multirow{2}{*}{ Satuan } & \multirow{2}{*}{ Bobot } & \multicolumn{3}{|c|}{ Skor } \\
\hline & & & $2(\mathrm{~S} 1)$ & 1 (S2) & $0(\mathrm{~N})$ \\
\hline Pengaruh Gelombang & & 4 & Kecil & Sedang & Besar \\
\hline Kecepatan Arus & $\mathrm{cm} /$ detik & 4 & $20-40$ & 10-19 dan 41-75 & $<10$ dan $>75$ \\
\hline Kedalaman & $\mathrm{m}$ & 3 & $5-7$ & $7,1-26$ & $<5$ dan $>26$ \\
\hline Oksigen terlarut & $\mathrm{mg} / \mathrm{l}$ & 2 & $>6$ & $4-6$ & $<4$ \\
\hline Kecerahan & $\mathrm{m}$ & 2 & $\geq 5$ & $3-<5$ & $<3$ \\
\hline Salinitas & $\%$ & 2 & $27-32$ & $20-26$ dan $33-35$ & $<20$ dan $>35$ \\
\hline Suhu & ${ }^{\circ} \mathrm{C}$ & 2 & $28-30$ & 25-27 dan 31-32 & $<25$ dan $>32$ \\
\hline Material dasar & & 2 & $\begin{array}{c}\text { berpasir dan } \\
\text { pecahan karang }\end{array}$ & Pasir Berlumpur & Berlumpur \\
\hline $\mathrm{pH}$ & & 1 & $6,5-8,5$ & $4-6,4$ dan $8,5-9,0$ & $<4$ dan $>9,5$ \\
\hline Fosfat & $\mathrm{mg} / \mathrm{l}$ & 1 & $0,2-0,5$ & $0,6-0,7$ & $<0,2$ dan $>0,8$ \\
\hline Nitrat & $\mathrm{mg} / \mathrm{l}$ & 1 & $0,9-3,2$ & $0,7-0,8$ dan $3,3-3,4$ & $<0,7$ atau $>3,4$ \\
\hline
\end{tabular}

Sumber: Modifikasi Bakosurtanal (1996), DKP (2002), DKP ( 2003), Romimohtarto (2003), KLH (2004), Radiarta et al (2003),

Rachmansyah (2004), Gufron dan Kordi (2005), Wibisono (2005)

Keterangan: Skor 2 : Sesuai; Skor 1 : Kurang Sesuai; Skor 0 : Tidak Sesuai

\section{Estimasi Beban Limbah Akibat Budidaya Laut}

Pendekatan estimasi beban limbah budidaya yang diterapkan dalam studi ini mengacu pada penelitian sebelumnya (Usman et al., 2001) dan merupakan pengembangan formula estimasi dari beban pakan yang masuk keperairan. Limbah kegiatan budidaya yang dijadikan dasar perhitungan dalam kajian ini adalah limbah budidaya ikan kerapu. Beban limbah senyawa Nitrogen dari kegiatan budidaya ikan dihitung dengan asumsi sebagai berikut:

- Kebutuhan pakan untuk produksi 1 ton ikan kerapu $=2.200 \mathrm{~kg}$.

- Dari analisa proksimat didapat kandungan $\mathrm{N}$ pelet (tergantung merk pakan) ikan kerapu = $181,5 \mathrm{~kg} \mathrm{~N} / 2.200 \mathrm{~kg}$ pelet.

- Pakan sebagai uneaten food $=200 \mathrm{~kg}$ dengan $\mathrm{N}=16,5 \mathrm{~kg}$.

- Pakan yang dimakan $=2.000 \mathrm{~kg}$ dengan $\mathrm{N}=$ $165 \mathrm{~kg}$; dikeluarkan melalui feses (tidak tercerna) $=840 \mathrm{~kg}$ dengan $\mathrm{N}=26,7 \mathrm{~kg}$; pakan yang dicerna $=1160 \mathrm{~kg}$ dengan $\mathrm{N}=138,3 \mathrm{~kg}$ dimana sebagian akan dibuang melalui ekskresi dan panas $=107,8 \mathrm{~kg} \mathrm{~N}$ dan tersimpan dalam daging $=30,5 \mathrm{~kg} \mathrm{~N}$.

\section{Analisis Komponen Utama (Principal Component Analysis/PCA)}

Analisis PCA adalah salah satu metode statistik multivariat yang digunakan untuk mengekstraksi hubungan linear antara berbagai parameter. Pada penelitian ini digunakan untuk mengidentifikasi kelompok atau kumpulan variabel yang memiliki kesamaan dan memungkinkan untuk melakukan penyederhanaan deskripsi dari hasil observasi. Hal tersebut dilakukan dengan menemukan struktur atau pola dari kelompok data yang beragam (Wiyoto \& Efendi, 2020). Persamaan umum untuk analisis PCA adalah :

$$
\begin{aligned}
& P C_{1}=a_{11} X_{1}+a_{21} X_{2}+\ldots . .+a_{p 1} X_{p}+\varepsilon_{1} \\
& P C_{2}=a_{12} X_{1}+a_{22} X_{2}+\ldots . .+a_{p 2} X_{p}+\varepsilon_{2} \\
& P C_{k}=a_{12} X_{1}+a_{22} X_{2}+\ldots . .+a_{p k} X_{p}+\varepsilon_{i}
\end{aligned}
$$


Persamaan di atas menunjukkan bahwa variabel baru yaitu PC adalah kombinasi linier dari variabel awal. PC1 adalah variabel yang menjelaskan keragaman paling besar diikuti oleh PC2, PC3 dan seterusnya. PCA menjamin bahwa PC1, PC2, PC3 saling bebas. Pada regresi ridge, variabel PC1, PC2, PC3 inilah yang akan menggantikan variabel awal.

\section{HASIL PEMBAHASAN}

\section{Karakteristik Kualitas Air Pesisir}

Pengukuran parameter kualitas air di perairan pesisir Kabupaten Situbondo dilakukan di 9 kecamatan dari arah barat ke timur. Kecamatankecamatan tersebut yaitu Besuki, Suboh, Mlandingan, Bungatan, Kendit, Arjasa, Jangkar, Asembagus dan Banyuputih. Sedangkan untuk wilayah Kabupaten Banyuwangi, pengukuran kualitas air dilakukan di 6 kecamatan yaitu Wongsorejo, Kalipuro, Muncar, Tegaldlimo, Bangorejo dan Pasanggaran. Pengukuran dilakukan selama 2 bulan dengan pengulangan setiap minggu. Rata-rata hasil pemngukuran kualitas air dapat dilihat pada Gambar 2.

Berdasarkan hasil pengukuran lapang suhu di perairan laut Kabupaten Situbondo dan Banyuwangi mempunyai kisaran antara 27$30^{\circ} \mathrm{C}$, dengan rata-rata sekitar $29^{\circ} \mathrm{C}$. Suhu perairan laut pada masing-masing stasiun pengamatan di tiap kecamatan relatif stabil, dengan peningkatan yang tidak terlalu drastis. Perbedaan suhu diantara lokasi pengamatan kecamatan tidak berada pada kisaran yang lebar. Kondisi terebut terjadi karena stasiun pengamatan berada lokasi perairan laut yang hampir memiliki kesamaan. Selain itu, pada umumnya perairan di negara dengan iklim tropis seperti Indonesia tidak mempunyai fluktuasi suhu yang besar. Kisaran suhu hasil pengukuran $\left(27,7^{\circ} \mathrm{C}-31^{\circ} \mathrm{C}\right)$ sesuai dengan yang dibutuhkan oleh rumput laut (Eucheuma sp), ikan kerapu dan kakap agar dapat tumbuh dengan baik.

Pengukuran salinitas pada tiap lokasi cenderung berbeda, diduga karena adanya aliran air dari sungai kecil yang bermuara di beberapa stasiun tersebut, sehingga terjadi percampuran air laut dengan air tawar dari sungai yang mengakibatkan sedikit berbeda salinitasnya. Selain itu juga stasiun pengamatan di Kecamatan Kendit memiliki kecenderungan menerima limbah dari pelabuhan di Kecamatan Panarukan, karena masih posisinya didalam kawasan teluk yang langsung berhubungan dengan kegiatan di pelabuhan. Salinitas di perairan pesisir Kabupaten Banyuwangi menunjukkan kisaran yang relatif tinggi yaitu antara 33 ppt-35 ppt, terutama untuk wilayah yang berada di perairan Sanudera Hindia (Kecamatan Tegaldlimo, Bangorejo dan Pasanggaran). Salinitas perairan laut relatif tinggi terutama di bagian selatan diduga karena berbatasan langsung dengan laut bebas dan tidak ada pengaruh aliran sungai dari darat. Budidaya rumput laut (Eucheuma sp) dapat tumbuh dengan baik pada perairan laut dengan salinitas antara 28 ppt-35 ppt, ikan dan tiram antara 31 ppt-34 ppt sedangkan salinitas optimum adalah 22 ppt-33 ppt.

Kedalaman perairan laut yang diukur pada penelitian ini adalah kedalaman lokasi budidaya laut (permukaan laut) sampai ke substrat dasar perairan. Kedalaman perairan terkait erat dengan kemampuan daya tembus cahaya matahari ke kolom air yang penting bagi pertumbuhan komoditas yang dibudidayakan. Berbeda dengan budidaya rumput laut yang membutuhkan perairan laut relatif dangkal, untuk budidaya ikan kerapu dan kakap sistem keramba jaring apung idealnya pada kedalaman antar 7 m-40 m, sedangkan tiram mutiara 10 m$20 \mathrm{~m}$ (Effendi 2004). Selain pengaruhnya terhadap intensitas cahaya matahari yang masuk, kondisi dimana perairan dengan kedalaman $<7$ meter dapat mempengaruhi kualitas perairan terutama dari sisa kotoran ikan yang membusuk didasar perairan.

Faktor cahaya merupakan salah satu penentu kehidupan dan tumbuh rumput laut serta tiram mutiara. Kecerahan perairan laut terkait erat dengan sejauh mana penetrasi cahaya matahari dapat masuk ke perairan yang dibutuhkan untuk proses fotosintesis, serta terkait erat dengan sebaran plankton. Hasil pengukuran kecerahan perairan laut pada masing-masing stasiun pengamatan di ketahui bahwa, secara umum rata-rata kecerahan perairan laut Kabupaten Situbondo berkisar antara 1,23 m-3,6 m. Berdasarkan data lapang menunjukkan bahwa kondisi kecerahan di perairan laut di lokasi penelitian > 1 meter. Kondisi ini menunjukkan kesesuaian untuk pertumbuhan rumput laut, serta dapat untuk budidaya ikan kerapu dan kakap tetapi kurang baik untuk pertumbuhan tiram mutiara yang membutuhkan kecerahan relatif lebih tinggi $(>3,5 \mathrm{~m})$. 


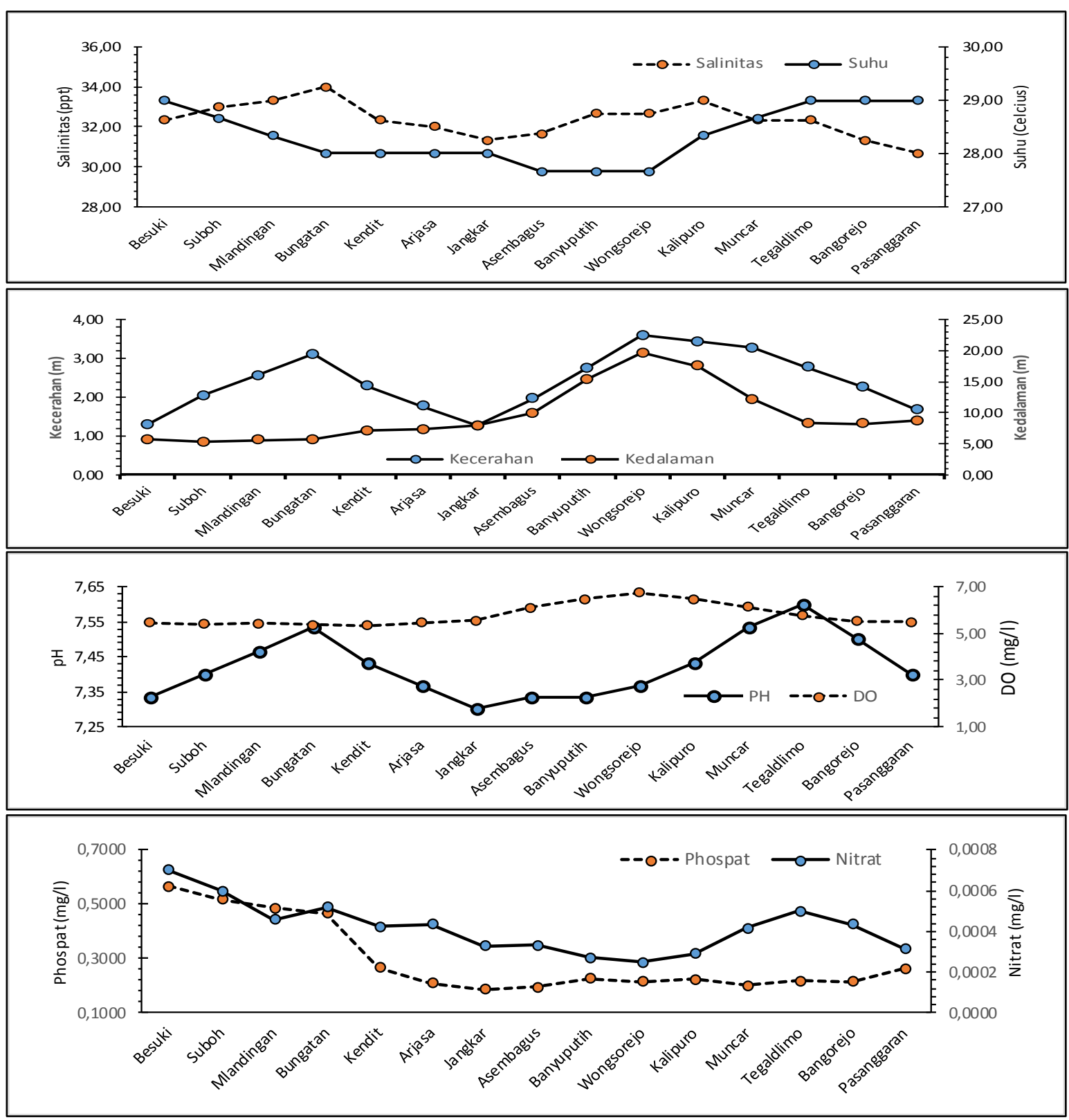

Gambar 2. Grafik Rata-rata Hasil Pengukuran Kualitas Air Pesisir Kabupaten Situbondo dan Banyuwangi Bulan Juni-Juli 2020

Hasil pengukuran $\mathrm{pH}$ perairan laut Kabupaten Situbondo dan Banyuwangi pada masing-masing kecamatan di ketahui bahwa, secara umum $\mathrm{pH}$ perairan laut berada pada kisaran 7,3 sampai 7,6. Kisaran $\mathrm{pH}$ perairan laut yang masih alami, menurut Mukhtasor (2007) berada pada kisaran sekitar 7,4 sampai 8,5 . Apabila nilai $\mathrm{pH}$ kurang atau melebihi kisaran tersebut mengindikasikan bahwa diperairan terjadi pencemaran atau akibat tingginya aktivitas biologis. Hasil pengamatan kondisi perairan laut di Kabupaten Situbondo menunjukkan bahwa di sekitar Kecamatan Besuki, Mlandingan, Arjasa dan Jangkar terindikasi adanya cemaran biologis karena $\mathrm{pH}$ perairan kurang dari 7,4.

Hasil pengukuran DO dari seluruh stasiun menunjukkan kisaran yang memenuhi syarat untuk hidup dan tumbuh biota laut yaitu 5,3 ppm sampai $6,9 \mathrm{mg} / \mathrm{l}$. Hal tersebut sangat dipengaruhi oleh sirkulasi perairan laut yang baik, didukung oleh kecepatan arus yang optimal (>15 cm/detik) bagi usaha budidaya rumput laut. Arus yang mengalir melewati selat madura berperan penting terhadap relatif tingginya konsentrasi DO di perairan laut Kabupaten Situbondo dan Banyuwangi. 
Hasil analisis konsentrasi nitrat pada perairan berada pada kisaran 0,0001-0,00099 mg/l. Hasil tersebut mengindikasikan bahwa perairan tersebut kurang subur. Waktu pengambilan sampel yang dilaksanakan pada bulan Juni-Juli (musim peralihan) dengan kondisi laut relatif berombak, diduga mempengaruhi distribusi dan konsentrasi nitrat di perairan. Sementara itu, konsentrasi phospat di perairan laut Kabupaten Situbondo dan Banyuwangi mempunyai ratarata $>0.2 \mathrm{mg} / \mathrm{l}$. Kisaran nilai phospat yang diperoleh di seluruh kecamatan jika dibandingkan dengan KEPMENLH nomor 51 tahun 2004 tentang baku mutu air laut bagi biota sudah melebihi batas nilai yang ditentukan yaitu $0,013 \mathrm{mg} / \mathrm{l}$.

\section{Kesesuaian Lokasi Budidaya Laut}

Nilai skor kesesuaian bagi budidaya ikan kerapu dan rumput laut dengan sistem keramba jaring apung (KJA) di Kabupaten Situbondo secara umum mempunyai kisaran sebesar 52,08 (Kecamatan Banyuputih) sampai 70,83 (Kecamatan Suboh). Evaluasi terhadap nilai tersebut menunjukkan bahwa berdasarkan semua parameter Kualitas air yang diukur dibandingkan dengan kriteria kesesuaian, memperlihatkan perairan laut Kecamatan Besuki, Suboh, Kendit, Arjasa dan Jangkar sesuai (S1) untuk dimanfaatkan sebagai lokasi pengembangan budidaya ikan kerapu dan rumput laut menggunakan sistem KJA (Gambar 3).

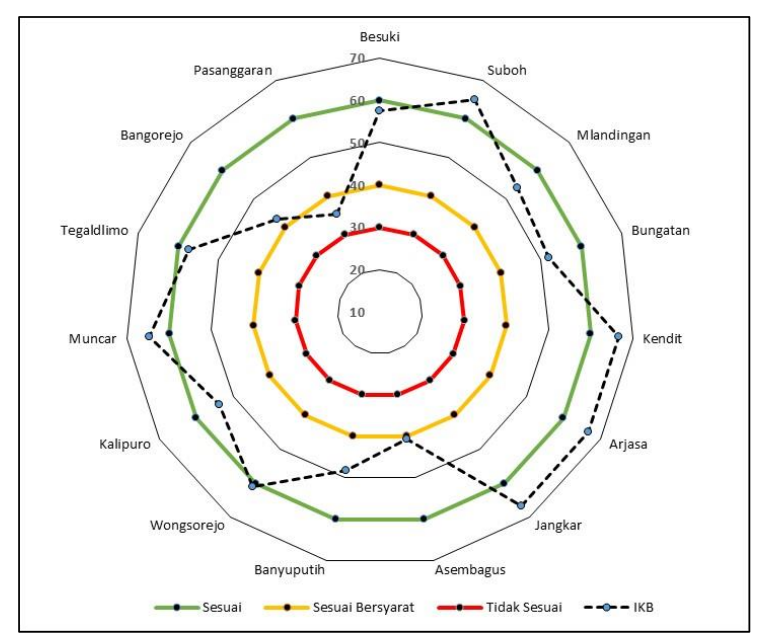

Gambar 3. Grafik Penilaian Indeks Kesesuaian Lokasi Budidaya Laut (IKB)

Selanjutnya nilai skor kesesuaian budidaya laut di Kabupaten Banyuwangi secara umum mempunyai kisaran sebesar 47,92 (Kecamatan Pasanggaran) sampai dengan 70,83 (Kecamatan Wongsorejo). Evaluasi terhadap nilai tersebut menunjukkan bahwa berdasarkan semua parameter Kualitas air yang diukur dibandingkan dengan kriteria memperlihatkan perairan laut Kecamatan Wongsorejo, Muncar dan Tegaldlimo sesuai (S1) untuk dimanfaatkan sebagai lokasi pengembangan budidaya laut.

\section{Analisis Beban Limbah}

Pendekatan estimasi beban limbah budidaya yang diterapkan dalam studi ini mengacu pada penelitian Usman et al. (2001) dan Kurniati (2013) yang merupakan pengembangan formula estimasi dari beban pakan yang masuk keperairan untuk komoditas kerapu dan ikan budidaya lain (bandeng/kakap). Limbah kegiatan budidaya yang dijadikan dasar perhitungan dalam studi ini adalah limbah budidaya dalam karamba jaring apung (KJA). Pada budidaya kerapu, waktu pemeliharaan hingga waktu pemanenan yang lebih lama yaitu sekitar 6 bulan serta limbah yang dihasilkan berupa feses lebih besar dibandingkan dengan limbah dari komoditas ikan budidaya lain yaitu $840 \mathrm{~kg}$ (Usman et al., 2001). Sedangkan lama pemeliharaan bandeng/kakap $\pm 4-5$ bulan dengan limbah berupa feses sebesar $312-540$ $\mathrm{kg} /$ ton ikan (Kurniati, 2013).

Nilai estimasi beban limbah yang masuk ke kawasan perairan studi adalah sebagai berikut:

- Satu unit keramba dalam studi ini diestimasikan terdiri dari 10 buah petakan keramba dengan ketentuan 9 buah keramba dimanfaatkan sebagai sarana produksi dan 1 petakan keramba dijadikan sebagai rumah jaga atau digunakan untuk keperluan lainnya. Sehingga setiap unit keramba hanya ada 9 keramba yang dioperasikan untuk membudidayakan ikan kerapu. Jika dalam 1 unit keramba serentak ditebar dengan benih ikan, sehingga 1 unit keramba berisi \pm 4.050 ekor ikan kerapu (padat tebar $16 \mathrm{ekor} / \mathrm{m}^{3}$ ). Selama masa pemeliharaan diasumsikan tingkat kelulushidupan ikan sebesar $80 \%$, sehingga pada saat pemanenan diperkirakan total biomass ikan kerapu adalah 3.240 ekor. Jika bobot individu ikan 500g/ekor maka dalam satu siklus pemeliharaan ( 6 bulan) 
didapat total produksi sebesar 1,62 ton ikan kerapu/unit.

- Diketahui produksi total 1,62 ton ikan kerapu dengan kebutuhan pakan sebanyak 2,2 ton untuk memproduksi 1 ton ikan dengan kandungan N sebesar 8,25 \%. Dengan demikian, jumlah pakan yang dibutuhkan untuk produksi ikan sebanyak 1,62 ton adalah 3,56 ton pakan dengan $\mathrm{N}$ sebesar 0,29 ton.

- Pakan sebagai Uneaten Food

Dari sejumlah pakan yang diberikan, tidak dimakan oleh ikan sebesar $9 \%$ dengan kandungan $\mathrm{N}$ sebesar $8,25 \%$, sehingga dapat dilakukan perhitungan sebagai berikut:

$$
\begin{aligned}
& U F=3,56 \times \frac{9}{10}=0,32 \text { ton } \\
& N=0,32 \times \frac{8,25}{100}=0,03 \text { ton }
\end{aligned}
$$

- Jika diketahui pakan yang dimakan oleh ikan sebanyak $91 \%$ dengan kandungan $\mathrm{N}$ sebesar 8,25\%; dengan demikian dari 3,56 ton pakan yang diberi pada ikan budidaya selama enam bulan masa pemeliharaan yang dimakan adalah 3,24 ton dengan kandungan $\mathrm{N}$ sebesar 0,27 ton.

- Banyaknya feses yang dikeluarkan oleh ikan yang dipelihara adalah sekitar $42 \%$ dari pakan yang dimakan dengan kandungan $\mathrm{N}$ sebesar 3,2 \%; sehingga dari pakan sebanyak 3,24 ton yang dimakan oleh ikan, yang dikeluarkan menjadi feses sebanyak 1,36 ton dengan kandungan $\mathrm{N}$ sebesar 0,04 ton.

- Sejumlah pakan yang dimakan oleh ikan, yang dicerna hanya $58 \%$ dengan kandungan $\mathrm{N}$ sebesar 11,9\%. Dengan demikian, dari 3,24 ton pakan yang dimakan oleh ikan, yang dicerna adalah sebesar 1,88 ton dengan kandungan $\mathrm{N}$ sebesar 0,22 ton.

- Dari sejumlah pakan yang dicerna, dikeluarkan oleh ikan berupa panas dan ekskresi lain di dapat kandungan N-nya sebesar 9,29 \% serta kandungan $\mathrm{N}$ yang tersimpan dalam daging sebesar $2,63 \%$. Sehingga dari 1,88 ton pakan yang dicerna, yang dikeluarkan berupa panas dan ekskresi lain memiliki $\mathrm{N}$ sebesar 0,17 ton; yang tersimpan dalam daging sebesar 0,05 ton $\mathrm{N}$.

- Berdasarkan perhitungan di atas, didapatkan jumlah total loading $\mathrm{N}$ dari kegiatan budidaya sistem keramba jaring apung keperairan selama masa pemeliharaan adalah sebesar 0,24 ton $N$ yang di dapat dari hasil penjumlahan total nitrogen pakan yang menjadi uneaten food dengan nitrogen pakan yang dikeluarkan berupa feses dan nitrogen pakan yang dikeluarkan berupa panas serta ekskresi lainnya.

Tabel 6.1. Estimasi Beban Limbah Kegiatan

\begin{tabular}{|c|c|c|}
\hline Variabel & $\begin{array}{l}\text { Bobot } \\
\text { (ton) }\end{array}$ & $\begin{array}{c}\mathrm{N} \\
\text { (ton) }\end{array}$ \\
\hline $\begin{array}{l}\text { - Jumlah Total Pakan untuk 1,62 ton } \\
\text { ikan (2,2 ton/tiap produksi } 1 \text { ton } \\
\text { ikan dengan N 8,25\%) }\end{array}$ & 3,56 & 0,29 \\
\hline $\begin{array}{l}\text { - Uneaten food (9 \% dari total pakan } \\
\text { dengan kandungan N 8,25\%) }\end{array}$ & 0,32 & 0,03 \\
\hline $\begin{array}{l}\text { - Pakan yang dimakan ( } 91 \% \text { dari } \\
\text { pakan yang diberikan dengan } \mathrm{N} \\
8,25 \%)\end{array}$ & 3,24 & 0,27 \\
\hline $\begin{array}{l}\text { - Fases (42\% dari pakan yang } \\
\text { dimakan dengan N 3,2\%) }\end{array}$ & 1,36 & 0,04 \\
\hline $\begin{array}{l}\text { - Tercerna (58 \% dari pakan yang } \\
\text { dimakan dengan N } 11,9 \% \text { ) }\end{array}$ & $\begin{array}{c}1,88 \\
-\end{array}$ & 0,22 \\
\hline $\begin{array}{l}\text { - Ekskresi (9,29\% dari pakan yang } \\
\text { dimakan) }\end{array}$ & $\begin{array}{l}- \\
-\end{array}$ & 0,17 \\
\hline $\begin{array}{l}\text { - N dalam daging ( } 2,63 \% \text { dari pakan } \\
\text { yang dimakan) }\end{array}$ & & 0,05 \\
\hline - Loading N (UF+Fases+Ekskresi) & & 0,24 \\
\hline
\end{tabular}
Budidaya Kerapu Sistem KJA

\section{Analisis Komponen Utama (Principal Component Analysis)}

Analisis Komponen Utama (PCA) dilakukan untuk meilhat keterkaitan anta parameter kualitas perairan. Eigenvalue merupakan suatu nilai yang menginterpretasikan seberapa besar variansi yang mampu diwakili oleh komponen tersebut. Hasil Analisa Komponen Utama memperlihatkan bahwa informasi penting terhadap sumbu terpusat pada 4 sumbu utama (F1, F2, F3, F4) dengan kontribusi masing masing faktor sebesar 46,91\%, 24,06\%, 19,12\% dan $6,33 \%$, serta kontribusi kumulatif terhadap keragaman sebesar 96,43\% (Gambar 4).

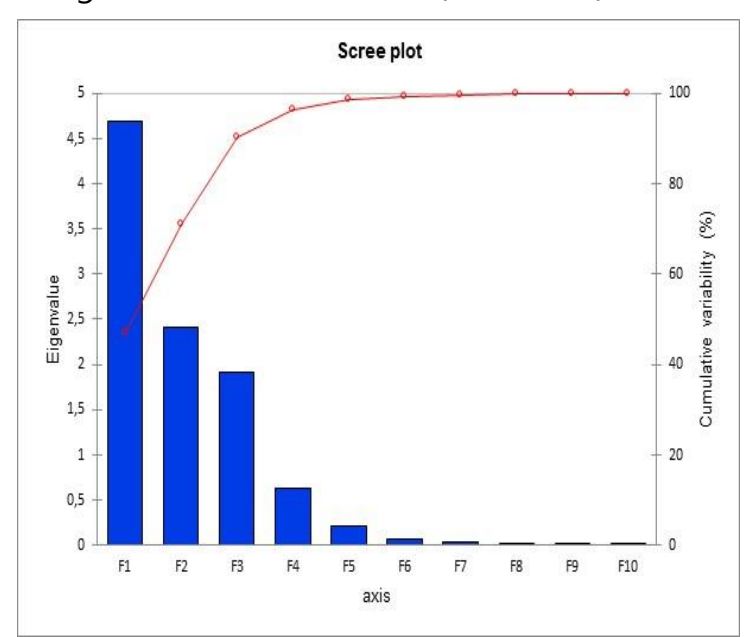

Gambar 4. Nilai Eigenvalue per Faktor dan Kumulatif Hasil Analisis PCA 


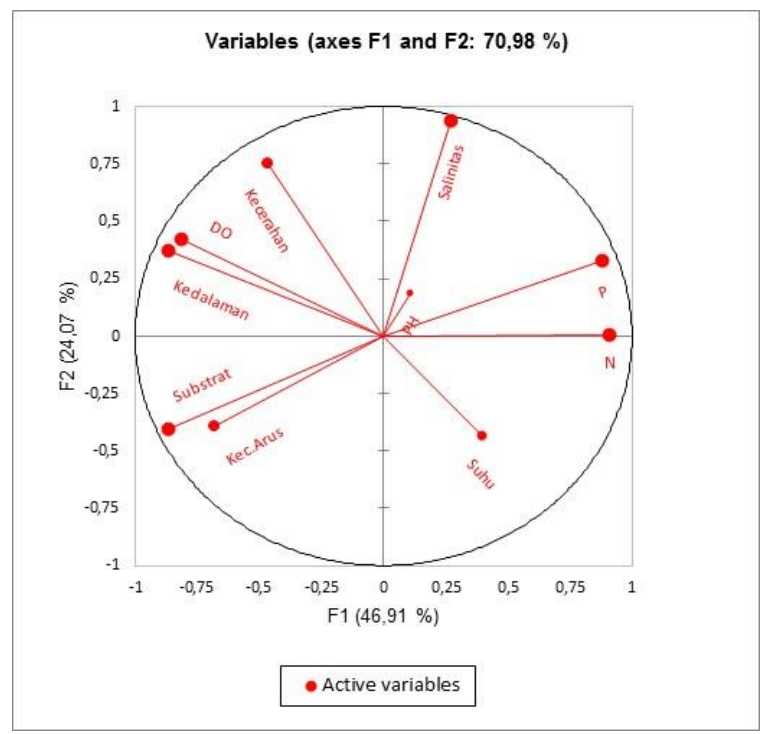

Gambar 5. Grafik Korelasi antar Parameter Kualitas Air

Grafik diatas menunjukkan korelasi antar parameter kualitas air yang diukur di lokasi penelitian. Terlihat bahwa nilai parameter kualitas air menempati kuadran I sampai dengan IV. Hubungan korelasi positif dapat terlihat pada nilai yang berada pada kuadran yang sama, misalnya pada kuadran I (kecerahan, DO dan kedalaman), kuadran II (salinitas, $\mathrm{pH}$, konsentrasi $\mathrm{N}$ dan $\mathrm{P}$ ) dan kuadran IV (jenis subtrat dan kecepatan arus). Sementara korelasi positif dapat dilihat dari nilai yang berada pada kuadran yang berseberangan (kuadran I dan III atau II dan IV).

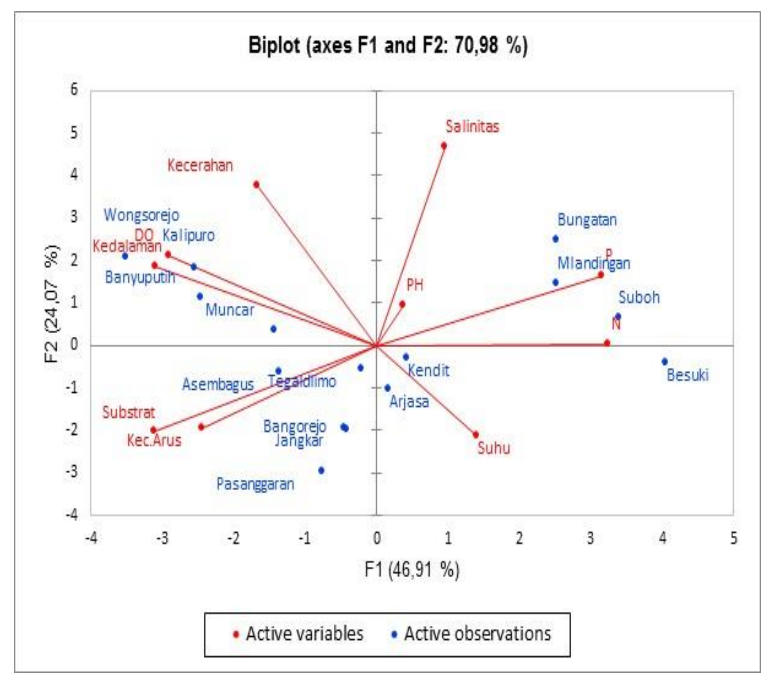

Gambar 6. Pengelompokan Stasiun Berdasarkan Nilai Parameter Kualitas Air

Selanjutnya hasil analisis PCA menunjukkan sebaran stasiun berdasarkan ciri dari nilai parameter kualitas perairan. Hasil tersebut menunjukkan bahwa stasiun yang terletak di Kecamatan Wongsorejo, Kalipuro, Muncar dan
Banyuputih dicirikan oleh kecarahan, DO dan kedalaman. Sementara itu untuk stasiun yang terletak di Kecamatan Bungatan, Mlandingan dan Suboh cenderung memiliki ciri pembeda yaitu salinitas, $\mathrm{pH}$, konsentrasi $\mathrm{N}$ dan $\mathrm{P}$. Nilai parameter suhu menjadi ciri untuk kelompok stasiun yang berada di Kecamatan Besuki. Kendit dan Arjasa. Lebih lanjut, stasiun pengamatan di Kecamatan Asembagus, Tegaldlimo, Bangorejo, Jangkar dan Pasanggaran dapat dibedakan berdasarkan karakteristik jenis subtrat dan kecepatan arus.

\section{KESIMPULAN DAN SARAN Kesimpulan}

Berdasarkan hasil analisa pada penelitian dapat disimpulkan bahwa lokasi yang sesuai untuk pengembangan budidaya laut di Kabupaten Situbondo terletak di Kecamatan Suboh, Kendit, Arjasa dan Jangkar dengan nilai indeks kesesuaian berkisar antara 63,5-67,5. Sementara untuk Kabupaten Banyuwangi, kawasan yang sesuai untuk pengembangan budidaya laut terletak di Kecamatan Wongsorejo dan Muncar dengan nilai indeks antara $64-68.5$. Pendugaan beban limbah KJA untuk budidaya kerapu adalah 0,24 ton N/10 unit karamba. Selanjutnya, hasil analisis karakteristik kualitas air menggunakan metode PCA diperoleh hasil bahwa kelompok-kelompok stasiun pengamatan memiliki karakteristik nilai parameter kualitas air yang berbeda-beda.

\section{Saran}

Berdasarkan hasil analisis dan kajian yang telah dilakukan pada studi ini, kajian sosiokultural masyarakat setempat sangat diperlukan untuk melengkapi kajian ini. Hal tersebut penting agar dapat menghasilkan kebijakan perencanaan pengembangan kegiatan budidaya laut dan perencanaan pemanfaatan ruang agar tidak menimbulkan tumpang tindih kepentingan dan dapat menciptakan konflik pemanfaatan.

\section{DAFTAR PUSTAKA}

Arifin, T., Bohari, R., \& Arlyza, I. S. (2014). Analisis Kesesuaian Ruang Berbasis Budidaya Laut di Pulau-pulau Kecil Makassar: Aplikasi Sistem Informasi Geografis. Forum Geografi, 28 (1)(1), 91-102.

Arisandi, A., Tamam, B., \& Fauzan, A. (2018). Profil Terumbu Karang Pulau Kangean, 
Kabupaten Sumenep, Indonesia [Coral Reef Profile of Kangean Island, Sumenep District, Indonesia]. Jurnal Ilmiah Perikanan Dan $\begin{array}{lll}\text { Kelautan, } & 10 & \text { (2), }\end{array}$ https://doi.org/10.20473/jipk.v10i2.10516

Bramana, A., Damar, A., Kurnia, R. (2014). Estimasi Daya Dukung Lingkungan Keramba Jaring Apung Perairan Pulau Semak Daun Kepulauan Seribu DKI Jakarta. Jurnal Teknologi Perikanan Dan Kelautan, 5(2), 161-170.

Dahuri R, Rais J, Ginting S P dan Sitepu M J. 2004. Pengelolaan Sumberdaya Pesisir dan Lautan Secara Terpadu. PT. Pradnya Paramita. Jakarta.

Effendi, H. 2003. Telaah Kualitas Air Bagi Pengelolaan Sumberdaya dan Lingkungan Perairan. PT. Kanisius. 257-258 hal.

FAO [Food Agriculture Organization]. 2006. State of the World's Fisheries and Aquaculture. Rome, FAO Italy. 162 hal. (available at http://www.fao.org/docrep/009/A0699e/ A0699E00.htm\#Contents). Fast AW. 1983. Ponds Production Sustems: Water Quality Management Practices. 145 - 168 hal.

Harianto, E., \& Efendi, I. (2017). Analisis Fisika Kimia Perairan untuk Pemilihan Lokasi Budidaya Ikan Kerapu (Serranidae) di Teluk Saleh Kabupaten Sumbawa Nusa Tenggaran Barat denga Metode Storet dan Analisis Multivariat. Jurnal Akuakultur Sungai Dan Danau, 2(1), 25-42.

Idris I, Ginting S P dan Budiman. 2007. Membangunkan Raksasa Ekonomi: Sebuah Kajian Terhadap Perundangundangan Pengelolaan Wilayah Pesisir dan Pulau-pulau Kecil. Penerbit Buku Ilmiah Populer. 296 hal.

Marpaung, L. S., Wardiatno, Y., Setyobudiandi, I., \& Arifin, T. (2019). Daya Dukung Budidaya Ikan Kerapu Pada Keramba Jaring Apung Teluk Awang Dan Teluk Bumbang, Ntb.
Jurnal Teknologi Perikanan dan Kelautan, 9(1), 43-53.

https://doi.org/10.24319/jtpk.9.43-53

Mustafa, A. A., Tarunamulia, T., Hasnawi, H., \& Radiarta, I. N. (2017). Karakteristik Dan Kesesuaian Perairan Untuk Budidaya Rumput Laut Di Kabupaten Kepulauan Sangihe, Sulawesi Utara. Jurnal Riset Akuakultur, $12(2), 187$. https://doi.org/10.15578/jra.12.2.2017.187196

Parwinia, P., Fauzi, A., Soedharma, D., Taryoto, A., \& Boer, M. (2007). Pemodelan Ko-eksistensi Pariwisata dan Perikanan: Analisis Konvergensi -Divergensi (Kodi) di Selat Lembeh Sulawesi Utara. Jurnal Ilmu-Ilmu Perairan Dan Perikanan Indonesia, 14(1), 59-66.

Syafikri, D., Nurwahidah, S., \& Kautsari, N. (2019). Pemberdayaan Masyarakat Kawasan Konservasi Kramat, Bedil, dan Temudong melalui Pengembangan Ekowisata Bahari dan Budi Daya Rumput Laut. Agrokreatif Jurnal Ilmiah Pengabdian Kepada Masyarakat, 5(1), 1-10. https://doi.org/10.29244/agrokreatif.5.1.110

Wiyoto, W., \& Efendi, I. (2020). Analisis Kualitas Air Untuk Marikultur di Moro, Karimun, Kepulauan Riau Dengan Analisis Komponen Utama Analysis of Water Quality for Mariculture in Moro , Karimun, Riau Islands with. 9(June), 143-154.

Yunus, A. R., Budi, S., \& Salam, S. (2019). Analisis kelayakan lokasi budidaya metode karamba jaring apung di perairan desa pulau harapan sinjai. Journal of Aquatic Environment, 2(1), 5. 